Original research article

\title{
The correlation between family support and psychological well-being in patients with end-stage renal disease
}

\author{
Nur Aini *, Avina Cahyaning Wahyu \\ University of Muhammadiyah Malang, Faculty of Health Sciences, Nursing Department, Malang, East Java, Indonesia
}

\begin{abstract}
This study aimed to determine the correlation between family support and the psychological well-being of patients with end-stage renal disease. This study was designed as a cross-sectional observation analytic study. The samples were collected based on a purposive random sampling technique. The study instrument was a questionnaire about family support and Ryff psychological well-being. The data were analyzed using Spearman's correlation test. A total of 26 patients (93\%) had good family support with various emotional support. The majority of patients (20 patients, $71 \%$ ) had positive relationships with others. The correlation between family support and psychological well-being was moderate $(p=0.020, r=0.439)$, the family's involvement and attention to the end-stage renal disease patients increased the patients' psychological well-being. However, there was no significant difference $(p>0.05)$ between gender in the family support and the psychological well-being of end-stage renal disease patients or hemodialysis patients.
\end{abstract}

Keywords: End-stage renal disease; Family support; Hemodialysis patients; Psychological well-being

\section{Introduction}

The Global Burden of Disease (GBD) study in 2015 estimated that approximately 1.2 million people died annually worldwide due to kidney failure. This number has increased by $32 \%$ since 2005. Each year, around 1.7 million people are estimated to die because of acute kidney injury (AKI). The disease prevalence is growing due to the increased incidence of diabetes mellitus, hypertension, obesity, and population aging (Cukor et al., 2008; Kizilcik et al., 2012). AKI will further develop into chronic kidney failure (CKD) and subsequently become endstage renal disease (ESRD). ESRD is defined as the 5th stage of CKD or severe kidney failure, where the glomerular filtration rate is $<15 \mathrm{ml} / \mathrm{min} / 1.73 \mathrm{~m}^{2}$, so the patients require dialysis or kidney transplantation to improve their health (Chew et al., 2017; Turkistani et al., 2014).

Hemodialysis is the final treatment in ESRD patients and plays a pivotal role in palliative therapy. This therapy does not restore kidney function but only decreases the risk of damaging other organs. The patients will have to undergo lifelong hemodialysis procedures that affect patients' physical and psychological conditions (Wang and Chen, 2012). It has been reported that depression is the most common psychiatric complication among ESRD patients (Cukor et al., 2008).

Lifetime dependence on dialysis treatment, high mortality rates, and the adjustments to the sick condition can cause physical, economical, and social changes, as well as psychological effects such as depression, anxiety, hopelessness, fatigue, decreased quality of life, and increased suicide rates (Chew et al., 2017; Luyckx et al., 2018). Psychological changes that occur in patients can cause psychological well-being disorders (Luyckx et al., 2018; Wang and Chen, 2012). Depression is one of the most common psychological problems found in patients with hemodialysis, with a prevalence of $5 \%$ to $58 \%$ (Kiosses and Karathanos, 2012). The stress of long-term medical care and lifelong ESRD affects the patient and his or her family. According to the Beck Depression Index (BDI) scoring, 135 (75\%) of patients and 60 (33.4\%) of attendants or caregivers were found to be moderate to severely depressed (Saeed et al., 2012). Another study found that 82 people (27.9\%) out of 294 hemodialysis patients had depression (Kizilcik et al., 2012).

Psychological well-being refers to inter- and intra-individual levels of positive functioning, including one's relationships with others and self-referent attitudes that comprise one's sense of mastery and personal growth (Burns, 2017). Low psychological well-being can affect one's self-acceptance, the patient feels they have no purpose in life, no positive interactions are formed with the environment or other people, and it makes one unable to accept the strengths or weaknesses in their lives (Ryff and Singer, 1996).

Social support is the existence and awareness of people who are reliable, respectful and share their love with others. Social support can come from family, friends, or other people who are important to the patient's life. Family support can affect psychological well-being because the family plays a vital role in improving patients' health (Alexopoulou et al., 2016).

\footnotetext{
* Corresponding author: Nur Aini, Jl. Bendungan Sutami No. 188-A Malang 65145, East Java, Indonesia; e-mail: nuraini_fikes@umm.ac.id http://doi.org/10.32725/kont.2020.041 
Family support is one of the most crucial solutions when facing problems, especially health problems. It also acts as a form of prevention to reduce anxiety, so the view of life becomes broader and the person is not easily stressed (Ratna, 2010). Families have an important role because they provide physical and emotional assistance to family members with physical illness, mental illness, or other conditions (Alnazly, 2018). Families are the best caregiving source for patients undergoing hemodialysis and have a fundamental role in managing and improving the quality of life of hemodialysis patients (Sajadi et al., 2017). Several studies have demonstrated that social support is associated with improved outcomes and survival in several chronic illnesses. It was reported that social support has a significant effect on the general well-being of dialysis patients and their adaptation to treatment (Tel et al., 2011).

A study conducted in Haji General Hospital, Surabaya, Indonesia, showed that about $59.7 \%$ of hemodialysis patients received family support and $40.3 \%$ did not. Patients with lowfamily support experience 5.85 times worse quality of life than patients with good family support. Patients who lack family support will have a lower quality of life because it made them develop negative judgments about themselves and less motivated to maintain their health. At the same time, good quality of life is found in many respondents with good family support (Bestari, 2016).

Family support and psychological well-being have been reported in some previous studies (Alexopoulou et al., 2016; Sheikh et al., 2019; Tel et al., 2011). However, indicators or disturbed aspects of family support and psychological well-being in each gender still need to be investigated in detail. In relation to this issue, this study aimed to identify the correlations between family support and the psychological well-being of hemodialysis patients. This study gives a new insight into the healthcare settings in treating hemodialysis patients; not only focussing on physical aspects of patients, but also on family support and the psychological well-being of patients with endstage renal disease.

\section{Materials and methods}

\section{Research design and data collection}

This study was designed as a cross-sectional observation analytical study and was approved by the research and ethical committee of the Medical Faculty of the University of Muhammadiyah Malang (No. E.5.a/059/KEPK-UMM/III/2019). The study was conducted in March-April 2019 at Kanjuruhan Regional Public Hospital in Malang, East Java, Indonesia. There was one sample group in this study, the patients who live with family. A total of 28 people were selected according to the purposive random sampling technique. The limited number of surveyed people in this study was because only chronic renal failure patients without any other diseases were selected. In this study, the inclusion criteria were patients with end-stage renal disease undergoing hemodialysis treatment for at least six months, living with family, patient awareness, and not experiencing a decrease in physical condition. The exclusion criteria were patients living alone and experiencing any complications. All participants signed an informed consent form and were assured that their name and address would remain confidential.

In this study, the family support and psychological well-being of patients were investigated using a questionnaire. Family support was regarded as an independent variable, and psychological well-being as a dependent variable. The data collection tool was a questionnaire on sociodemographic characteristics, family support, and Ryff psychological well-being (PWB). The sociodemographic characteristics questions were age, duration of hemodialysis, gender, and occupation. The family support questionnaire was developed based on Friedman's family theory and previous studies in Indonesia (Friedman, 2010; Priyanti, 2015; Sidiq, 2014) because the questions were considered to be suitable to the characteristics of Indonesian people. The questionnaire consisted of 16 questions with four indicators: emotional support, information, instrument, and assessment. The questionnaire has been tested for its validity and reliability that showed valid and reliable results (Cronbach's $\alpha$ coefficient $=$ 0.935). The questions used a Likert scale with the following options: always (4), often (3), rarely (2), and never (1). The scores were combined into an index and categorized as good (49-64), sufficient (33-48), and less than sufficient (16-32).

We used PWB in this study since it is a self-rated instrument with good psychometric properties and clinical sensitivity, which assesses the positive functioning across different domains. The instrument has been validated across different countries, different populations, and in clinical settings ( $\mathrm{Ra}-$ fanelli and Ruini, 2011). Ryff's questionnaire of psychological well-being has six indicators: self-acceptance, positive relations with others, autonomy, environmental mastery, purpose in life, and personal growth. This questionnaire consisted of 42 questions: favorable (22 questions) and unfavorable (20 questions). The questions used a Likert scale with the options from strongly disagree (1 point) to strongly agree (6 points) (Ryff and Singer, 1996). Then, the score was categorized as low $=\langle 112$, moderate $=112-182$, and high $=\geq 182$. The questionnaire was tested for validity by Exploratory Factor Analysis (EFA) with the results of 0.306-0.731 and for reliability with a Cronbach's $\alpha$ of 0.845 , both indicating the questionnaire was valid and reliable.

\section{Data analysis}

The Spearman's rho values were used to determine the correlation between family support and psychological well-being, while the Mann-Whitney test was used to investigate the difference between variables in each gender. Descriptive statistics, including frequencies, percentages, means, and standard deviations, were used to describe the sociodemographic characteristics, family support, and psychological well-being. In all statistical analyses, a $p$-value $<0.05$ was considered significant. All data were analyzed using SPSS software version 20.0 (IBM).

\section{Results}

All participants in this study were chronic renal failure patients without any other diseases. The average age of the participants was $50.5+8.8$ years old. The average duration of hemodialysis was $20.17+15.6$ months. The gender composition of the study was $54 \%$ male $(n=15)$ and $46 \%$ female $(n=13)$ (Table 1$)$. Most of the participants worked as farmers $(n=10 ; 36 \%)$ (Chart 1$)$.

Table 1. The age and duration of hemodialysis of the endstage renal disease patients

\begin{tabular}{lcccc} 
Characteristics & Mean & SD & Min & Max \\
\hline Age (years old) & 50.50 & 8.8 & 36 & 65 \\
$\quad$ Male & 52.18 & 8.47 & 38 & 65 \\
Female & 48.25 & 9.04 & 36 & 64 \\
\hline Duration of hemodialysis (months) & 20.17 & 15.6 & 6 & 60 \\
\hline
\end{tabular}




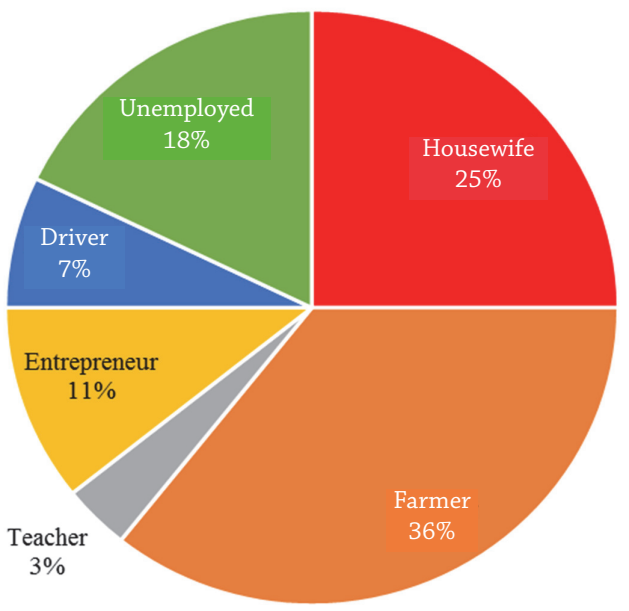

The majority of ESRD patients received good family support ( $n=26,93 \%)$ or moderate/sufficient support ( $n=2 ; 7 \%)$. Our study showed that only men receive sufficient support from their families. Furthermore, the highest family support was given in the form of emotional support (15.42 \pm 0.95$)$, and this support was higher in males than females. Between the four family support indicators, the lowest was the assessment support (14.17 \pm 2.61$)$. The assessment support for ESRD patients was higher in females than males, but not significantly different $(p>0.05)$ (Table 2).

The majority of ESRD patients had high psychological well-being ( $n=20,71 \%)$. The highest score was a positive relationship ( $34.57 \pm 4.76)$, with males higher than females. The lowest was self-acceptance $(31.07 \pm 4.23)$, with males higher than females, but not significantly different (Table 3 ).

Chart 1. The job status of the participants

Table 2. The family support level and its indicators of ESRD patients

\begin{tabular}{lcc} 
Family support & $n(\%)$ & $\begin{array}{c}\mathrm{X} \pm \mathrm{SD} \\
\text { (f: female, m: male) }\end{array}$ \\
\hline Less & 0 & \\
Sufficient & 7 (all male) \\
Good & 93 (m: $14 ; \mathrm{f}: 12)$
\end{tabular}

\begin{tabular}{|c|c|}
\hline \multicolumn{2}{|c|}{ Indicators } \\
\hline Emotional support & $\begin{array}{c}15.42+0.95 \\
(\mathrm{f}: 15.16+1.02 ; \mathrm{m}: 15.68+0.79), p=0.086^{*}\end{array}$ \\
\hline Information support & $\begin{array}{c}14.25+2.11 \\
\text { (f: } 14.41+1.83 ; \mathrm{m}: 14.37+2.09), p=0.942^{*}\end{array}$ \\
\hline Instrumental support & $\begin{array}{c}15.14+1.40 \\
(\mathrm{f}: 15.58+0.66 ; \mathrm{m}: 15.06+1.18), p=0.302^{*}\end{array}$ \\
\hline Assessment support & $\begin{array}{c}14.17+2.61 \\
(\mathrm{f}: 14.25+2.13 ; \mathrm{m}: 14.12+2.98), p=0.771^{*}\end{array}$ \\
\hline
\end{tabular}

Table 3. The psychological well-being indicators for patients

Psychological well-being

$n(\%)$

\begin{tabular}{lc}
\hline Low & 0 \\
Moderate & $29(\mathrm{~m}: 3 ; \mathrm{f}: 5)$ \\
High & 71 (m: 13; f: 7$)$ \\
\hline
\end{tabular}

\begin{tabular}{|c|c|}
\hline \multicolumn{2}{|c|}{ Dimension } \\
\hline Autonomy & $\begin{array}{c}31.32+5.67 \\
(\mathrm{f}: 30.91+6.27 ; \mathrm{m}: 31.62+5.36), p=0.624^{*}\end{array}$ \\
\hline Mastery of the environment & $\begin{array}{c}32.42+4.45 \\
\text { (f: } 31.41+4.42 ; \mathrm{m}: 33.18+4.46), p=0.414^{*}\end{array}$ \\
\hline Personal growth & $\begin{array}{c}33.89+5.06 \\
(\mathrm{f}: 33.08+5.88 ; \mathrm{m}: 34.5+4.45), p=0.402^{*}\end{array}$ \\
\hline Positive relationship & $\begin{array}{c}34.57+4.76 \\
(\mathrm{f}: 34.41+5.03 ; \mathrm{m}: 34.68+4.71), p=0.640^{*}\end{array}$ \\
\hline Purpose of life & $\begin{array}{c}33.75+5.20 \\
\text { (f: } 32.75+4.69 ; \mathrm{m}: 34.5+5.58), p=0.284^{*}\end{array}$ \\
\hline Self-acceptance & $\begin{array}{c}31.07+4.23 \\
(\mathrm{f}: 30+4.41 ; \mathrm{m}: 31.87+4.04), p=0.254^{*}\end{array}$ \\
\hline
\end{tabular}

$$
\mathrm{X} \pm \mathrm{SD}
$$

Family support and psychological well-being

$p=0.020$

$r=0.439$ 


\section{Discussion}

In this study, the majority of patients received good family support (Table 2). Some previous studies indicated that the prevalence of family support was excellent ( $n=62,60.79 \%)$ (Winata et al., 2017). However, our study contradicted that of Bestari (2016) - which stated 24 (82.8\%) hemodialysis patients receive less support. Priyanti (2015) also showed that $51.3 \%$ of patients receive less support. Furthermore, according to Kim and Kim (2019), the mean value of social support for hemodialysis patients was 44.9 in the range of 12-60.

Family support is grouped into four types: emotional, instrumental, information, and assessment. In this study (based on the questionnaire), emotional support is the most frequent support given to the patients by family members, i.e., the family always accompanies the patients during the therapy process, provide support so that patients do not feel alone, provide affection, listen to the patient's complaints so that the family knows the patient's current feelings, and provide encouragement and motivation so that the patient does not experience a decline in health status. Meanwhile, the lowest family support type in this study was the assessment support. For example, the family could not act as the facilitator in the problem-solving processes that the patient faced. Marcia and Lancaster (2014) stated that in assessment support, the family act as the middleman and the facilitator to help the patient solve their problems. The support and attention from the family is a positive award that can be given to the patient. In this study, there was no difference in the average family support for both males and females (Table 2).

Family support is the existence of interpersonal relationships that protect someone from the effects of stress. The interpersonal relations include attitudes, actions, and acceptance of a family member so that the ill family member feels someone is paying attention and loving them (Kaplan et al., 2010). Family is a support system that provides direct care for sick family members. Patients who received family support showed better adjustments to their health conditions and improved their health behavior (Singmanee et al., 2016).

Psychological well-being is an increase in individuals' concept of developing themselves to be happy; individuals have meaning in their lives and effectively present positive emotions such as satisfaction, happiness, confidence, and interest. Psychological well-being means more than being free from stress and not having other psychological problems (Ryff, 1995). In this study, the majority of patients had high psychological well-being (Table 3). However, this study is different from the previous study of Hamdan-Mansour et al. (2015), which showed that the hemodialysis patient had a mean score of 38.9 or a moderate level of psychological distress. Rezaei et al. (2018) stated that hemodialysis patients experienced psychological stress and exhaustion.

The highest scoring psychological well-being dimension in this study was positive relationships with others (Table 3). This is reflected in the patient's active interaction with others. Those with positive relationships are described as individuals who can love and foster interpersonal relationships that are built on mutual trust. Individuals who have strong feelings of empathy and care for fellow humans have deep friendships and good identification skills with others (Keyes et al., 2002).

The second-highest scoring dimension was personal growth. Patients used their lives as a process to learn and grow and do not easily give up on their condition. The individual who has reached this personal growth condition will not stop in a static condition and will continue to develop him or herself. He or she will be open-minded to experiences of diseases and other problems in his or her life. Normally, mature individuals will always be aware of their potency. A person in the personal growth dimension looks at themselves as an individual who is always growing, evolving, open to new experiences, self-aware, and can become a better person with a high and adequate capacity (Keyes et al., 2002; Saricaoğlu and Arslan, 2013).

The lowest scoring dimension in this study was self-acceptance. The patient feels that they are not good enough compared to normal people and always thinks that other people's lives are much better than theirs. According to Keyes et al. (2002), self-acceptance in psychological well-being is correlated with the ability of an individual to accept his or her present and past condition. This dimension also correlates with a positive assessment of the patient's health condition. An individual who has a good value in relation to the dimension of self-acceptance is able to understand and accept the various dimensions, including staying positive in their life.

The factors that need to be considered to understand someone's psychological well-being are not only family support, but also several other factors that affect psychological well-being, such as religiosity, personality, life experience, demographic factors (age, gender, socio-economic and cultural), and physical health (Ryff and Singer, 1996). Sociodemographic factors correlate with the life quality and psychological well-being of renal disease patients (Theofilou, 2012). Female patients are reported to face problems in their psychological well-being, social relationships, and general health (Shahgholian and Yousefi, 2015). However, in this study, although in general the average psychological well-being value was obtained for males, this was not statistically significant $(p>0.05)$, so it needed to be proven through further study (Table 3 ).

The result showed that there was family support accompanied by a good level of psychological well-being in hemodialysis patients, and the correlation between the two variables in this study was sufficient (Table 3). Better family support was correlated with the improvement of psychological well-being. Psychological well-being encompasses positive self-perception, positive relations with others, environmental mastery, autonomy, purpose in life, and emotions inclined towards health development. Poor psychological well-being has an impact on physical health conditions (Hamdan-Mansour et al., 2015). Our study was supported by a previous study, that better family adaptability and communication resulted in greater resilience, thus it is associated with better mental health (Kukihara et al., 2020). Family support affects the quality of life (Bestari, 2016), and the health behaviors of ESRD patient receiving family support was significantly higher than before receiving family support $(p<0.01)$ (Shahgholian and Yousefi, 2015).

Family support is needed for hemodialysis patients because it can increase psychological well-being and the ability to adjust the feeling of belonging, clarity of identity, increase self-esteem, and reduce stress. The emotional support from their family can help the patients to tolerate the disease, its treatment, and complications (Shahgholian and Yousefi, 2015). Social support is essential for the survival of community members, and especially for psychological well-being (Far and Jahangir, 2017). Lack of family support might exacerbate patients' negative feelings and psychological disturbances, so it contributes to depression, decreases the motivation to improve health conditions, and decreases the quality of life (Wang and Chen, 2012).

Family support can reduce the mortality rate of ESRD patients and improve their quality of life (Plantinga et al., 2010). 
The family is the most effective support for various aspects of life. Family support plays an important role for hemodialysis patients to get their normal and active life back (Naderifar et al., 2017). The family support can increase the psychological well-being and the ability of adaptation through feelings, identity clearance, increasing self-regard, decreasing stress, and providing needed sources.

Social support had a direct effect on psychological well-being and depression. Along with its indirect effect through self-esteem, the need for communication, and the need for competence, led to psychological well-being increase and depression reduction (Far and Jahangir, 2017). However, if a family member is suffering from chronic disease, sometimes the other member can also receive the tension. Therefore, the patient misunderstands and thinks that their family is abandoning him or her. According to previous studies, the family is the main source of support and the most important thing that the patient has. The highest level of social support is received from the family. Although the patients already have family support, they still feel like they need more support. Thus, the family must show their support to the ESRD patient (da Silva et al., 2016).

The strength of this study is that both variables (family support and psychological well-being) are discussed in detail.
Thus we know which aspects of family support should be improved. However, the limitation of this study was the small sample size because only 28 patients met the inclusion and exclusion criteria. Besides, the study was only conducted in one hospital; so it could not describe the problems of family support and psychological well-being of ESRD patients in general. The findings also need to be followed up through further study with a larger sample size.

\section{Conclusions}

There is a correlation between family support and psychological well-being in ESRD patients. The family's involvement and attention to the ESRD patients can increase their psychological well-being. Therefore, family should increase support and give more attention to ESRD patients, because they play an important role in ESRD patients successfully adapting to the disease.

\section{Conflict of interests}

The authors have no conflict of interests to declare.

\title{
Korelace mezi podporou rodiny a psychickou pohodou u pacientů v konečném stadiu onemocnění ledvin
}

\begin{abstract}
Souhrn
Cílem této studie bylo zjistit korelaci mezi podporou rodiny a psychickou pohodou pacientů v terminálním stadiu onemocnění ledvin. Tato studie byla koncipována jako průřezová pozorovací analytická studie. Vzorky byly shromážděny na základě účelové techniky náhodného vzorkování. Studijním nástrojem byl dotazník o podpoře rodiny a Ryffova stupnice psychické pohody. Data byla analyzována pomocí Spearmanova korelačního testu. Celkem 26 pacientů (93 \%) mělo dobrou rodinnou a emoční podporu. Většina pacientů (20 pacientů, $71 \%$ ) měla pozitivní vztahy s ostatními. Korelace mezi podporou rodiny a psychickou pohodou byla mírná ( $p=0,020, r=0,439)$, zapojení rodiny a pozornost věnovaná pacientům v konečném stadiu onemocnění ledvin zvýšila psychickou pohodu pacientů. Nebyl však žádný významný rozdíl $(p>0,05)$ mezi pohlavími v podpoře rodiny a psychickou pohodou pacientů v terminálním stadiu onemocnění ledvin nebo pacientů s hemodialýzou.
\end{abstract}

Klíčová slova: pacienti s hemodialýzou; psychická pohoda; rodinná podpora; terminální stadium

\section{References}

1. Alexopoulou M, Giannakopoulou N, Komna E, Alikari V, Polikandrioti M (2016). The effect of perceived social support on hemodialysis patients quality of life. Mater Sociomed 28(5): 338-342. DOI: $10.5455 / \mathrm{msm} .2016 .28 .338-342$.

2. Alnazly EK (2018). The impact of an educational intervention in caregiving outcomes in jordanian caregivers of patients receiving hemodialysis: a single group pre-and-post test. Int J Nurs Sci 5(2): 144-150. DOI: 10.1016/j.ijnss.2018.03.007.

3. Bestari AW (2016). Pengaruh dukungan keluarga dan status DM Terhadap kualitas hidup pasien hemodialisis. Jurnal Berkala Epidemiologi 4(2): 200-212.

4. Burns RA (2017). Psychosocial Well-Being. In: Pachana NA (Eds). Encyclopedia of Geropsychology. Singapore: Springer. DOI: 10.1007/978-981-287-082-7_251.

5. Chew STH, Ng RRG, Liu W, Chow KY, Ti LK (2017). Acute kidney injury increases the risk of end-stage renal disease after cardiac surgery in an Asian population: A prospective cohort study. BMC Nephrology 18(1): 1-8. DOI: 10.1186/s12882-0170476-y.
6. Cukor D, Coplan J, Brown C, Peterson RA, Kimmel PL (2008). Course of depression and anxiety diagnosis in patients treated with hemodialysis: A 16-month follow-up. Clin J Am Soc Nephrol 3(6): 1752-1758. DOI: 10.2215/cjn.01120308.

7. da Silva SM, Braido NF, Ottaviani AC, Gesualdo GD, Zazzetta MS, Orlandi F (2016). Social support of adults and elderly with chronic kidney disease on dialysis. Rev Lat Am Enfermagem 24: 1-13. DOI: 10.1590/1518-8345.0411.2752.

8. Far SM, Jahangir P (2017). The role of perceived social support and emotional regulation styles in predicting psychological wellbeing in people with diabetes. Revista Publicando 14: 194-213.

9. Friedman MM (2010). Buku ajar keperawatan keluarga: Riset, teori, dan praktek. Jakarta: EGC.

10. Hamdan-Mansour AM, Aboshaiqah AE, Thultheen IN, Salim WM (2015). Psychological wellbeing of saudi patients diagnosed with chronic illnesses. Psychology 6: 55-62. DOI: $10.4236 /$ psych.2015.61006.

11. Kaplan HI, Sadock B, Grebb JA (2010). Sinopsis psikiatri: Ilmu pengetahuan perilaku psikiatri klinis. Tangerang: Binarupa Aksara.

12. Keyes CLM, Shmotkin D, Ryff CD (2002). Optimizing wellbeing: The empirical encounter of two traditions. J Pers 
Soc Psychol 82(6): 1007-1022. DOI: 10.1037//00223514.82.6.1007.

13. Kim B, Kim J (2019). Influence of Uncertainty, Depression, and Social Support on Self-Care Compliance in Hemodialysis Patients. Ther Clin Risk Manag 15: 1243-1251. DOI: 10.2147/ TCRM.S218934.

14. Kiosses V, Karathanos V (2012). Depression in patients with CKD: A person centered approach. Journal of Psychology and Psychotherap 3(002): 1-5. DOI: 10.4172/2161-0487.s3-002.

15. Kizilcik Z, Sayiner FD, Unsal A, Ayranci U, Kosgeroglu N, Tozun M (2012). Prevalence of depression in patients on hemodialysis and its impact on quality of life. Pakistan Journal of Medical Science 28(4): 695-699.

16. Kukihara H, Yamawaki N, Ando M, Nishio M, Kimura H, Tamura Y (2020). The Mediating Effect of Resilience Between Family Functioning and Mental Well-Being in hemodialysis patients in Japan: A Cross-Sectional Design. Health and Quality of Life Outcomes 18(1): 1-8. DOI: 10.1186/s12955-02001486-x.

17. Luyckx VA, Tonelli M, Stanifer JW (2018). The Global burden of kidney disease and the sustainable development goals. Bull World Health Organ 96(6): 414-422. DOI: 10.2471/ blt.17.206441.

18. Marcia S, Lancaster J (2014). Public health nursing, populationcentered health care in the community. USA: Elsevier.

19. Naderifar M, Tafreshi MZ, Ilkhani M, Kavousi A (2017). The outcomes of stress exposure in hemodialysis patients. J Renal Inj Prev 6(4): 275-281. DOI: 10.15171/jrip.2017.52.

20. Plantinga LC, Fink NE, Harrington-Levey R, Finkelstein FO, Hebah N, Powe NR, Jaar BG (2010). Association of social support with outcomes in incident dialysis patients. Clin J Am Soc Nephrol 5(8): 1480-1488. DOI: 10.2215/cjn.01240210.

21. Priyanti WS (2015). Gambaran Dukungan Sosial Keluarga Pada Pasien Penyakit Ginjal Kronis Yang Menjalani Hemodialisis di RSUD Kraton Pekalongan. Jurnal Keperawatan FIKkeS Universitas Muhammadiyah Semarang 8(1): 1-10.

22. Ratna W (2010). Sosiologi dan antropologi kesehatan. Yogyakarta: Pustaka Rihama.

23. Rafanelli C, Ruini C. (2011). Assessment of Psychological WellBeing in Psychosomatic Medicine. Adv Psychosom Med 32: 182-202. DOI: 10.1159/000330021.

24. Rezaei Z, Jalali A, Jalali R, Khaledi-Paveh B (2018). Psychological Problems as The Major Cause of Fatigue in Clients Undergoing Hemodialysis : A Qualitative Study. International Journal of Nursing Sciences 5(3): 262-267. DOI: 10.1016/j. ijnss.2018.07.001.

25. Ryff CD (1995). Psychological well-being in adult life. Current Directions in Psychological Science 4: 99-104. DOI: 10.1111/1467-8721.ep10772395.

26. Ryff CD, Singer B (1996). Psychological well-being: Meaning, measurement, and implications for psychotherapy research. Psychother Psychosom 65(1): 14-23. DOI: 10.1159/000289026.
27. Saeed Z, Ahmad AM, Shakoor A, Ghafoor F, Kanwal S (2012). Depression in patients on hemodialysis and their caregivers. Saudi J Kidney Dis Transpl 23: 946-952. DOI: 10.4103/13192442.100869.

28. Sajadi SA, Ebadi A, Moradian ST (2017). Quality of life among family caregivers of patients on hemodialysis and its relevant factors: A systematic review review article. Int J Community Based Nurs Midwifery 5: 206-218.

29. Saricaoğlu H, Arslan C (2013). An investigation into psychological well-being levels of higher education students with respect to personality trait and self compassion. Educational Sciences: Theory \& Practice 13: 2097-2104. DOI: 10.12738/estp.2013.4.1740.

30. Shahgholian N, Yousefi H (2015). Supporting hemodialysis patients: a phenomenological study. Iran J Nurs Midwifery Res 20: 626. DOI: 10.4103/1735-9066.164514.

31. Sheikh MM, Qayyum R, Panda M (2019). Relationship of Physicians' Rapport With Patients' Satisfaction and Psychological Well-being During Hospitalization. Cureus 11(6): e4991. DOI: 10.7759/cureus.4991.

32. Sidiq R (2014). Hubungan Dukungan Keluarga dengan Kualitas Hidup Penderita Penyakit Ginjal Tahap Akhir yang Menjalani Terapi Hemodialisa di Badan Layanan Umum Daerah RSUD Dr. Zainoel Abidin Banda Aceh Tahun 2013. Idea Nursing Journal $\mathrm{V}(1): 41-48$

33. Singmanee C, Vannarit T, Tachaudomdach C (2016). Effect of family support on health behaviors among persons with end stage renal disease receiving continuous ambulatory peritoneal dialysis. International Journal of Evidence-Based Healthcare, 14: S31. DOI: doi.org/10.1097/01.xeb.0000511670.35292.8a.

34. Theofilou PA (2012). The impact of sociodemographic and psychological variables on quality of life in patients with renal disease: Findings of a cross-sectional study in Greece. World Journal of Nephrology \& Urology 1: 101-106. DOI: 10.4021/ wjnu44w.

35. Tel H, Tel H, Esmek M (2011). Quality of Sleep in Hemodialysis Patients. Dialysis \& Transplantation 27: 479-484. DOI: 10.1002/dat.20138.

36. Turkistani I, Nuqali A, Badawi M, Taibah O, Alserihy O, Morad M, Kalantan E (2014). The Prevalence of Anxiety and Depression Among End-Stage Renal Disease Patients on Hemodialysis in Saudi Arabia. Ren Fail 36(10): 1510-1515 DOI: 10.3109/0886022X.2014.949761.

37. Wang LJ, Chen CK (2012). The psychological impact of hemodialysis on patients with chronic renal failure. In: Polenakovic M (Eds). Renal failure-The fact. Crotia: Intech, pp. 217-236. DOI: 10.5772/36832.

38. Winata LCWP, Putranto W, Fanani M (2017). Association between Hemodialysis Adequacy, Family Support, and Quality of Life in Chronic Renal Failure Patients. Indonesian Journal of Medicine 02(01): 63-72. DOI: 10.26911/ theijmed.2016.01.03.07. 